\title{
Viral hepatitis in Danish health care personnel, 1974-78
}

\section{P SKINHØJ AND M SØEBY}

From the Department of Infectious Diseases, Rigshospitalet and The National Board of Health, Department D, Copenhagen, Denmark

SUMmaRY The incidence of viral hepatitis in Denmark, as notified to the National Board of Health during 1974-78, was determined for health care personnel. Compared to the rate for the population as a whole, a fivefold increase was found for physicians and surgeons as well as for laboratory technicians. Dentists also had an increased rate of infection. No increase was apparent for the nursing staff in general, or for psychiatric hospitals or institutions for the mentally retarded.

In hospitals, type B hepatitis was prevalent among doctors and technicians while $55 \%$ of the nursing staff did not have $B$ hepatitis.

For many years viral hepatitis has been recognised as an important occupational risk among health care personnel. ${ }^{1}$ Series of studies have provided information as to the sources and routes of infection as well as identification of groups at high risk..$^{2-5}$ Consequently, a number of prophylactic measures, such as serological screening programmes, patient isolation, and blood handling, have been established.

However, a continuous evaluation of the effect of these measures is rarely undertaken ${ }^{6} 7$ and reliable data on clinical disease rates are not readily available.

The present report attempts to analyse the number and distribution of notified cases of viral hepatitis in health care personnel in Denmark during 1974-78.

\section{Methods}

Viral hepatitis has been notified separately in Denmark for the past 12 years and includes the occupation of the patient and the presumed origin of infection. All notifications have been reviewed from 1974 to 1978 and those concerning health care personnel included in the present survey.

A further questionnaire concerning details of occupation, other sources of exposure apart from professional contact, department of work, as well as the result of tests for hepatitis B surface antigen (HBs Ag) by any method was completed by the physician in all cases where these data had not been given in the original notification.

\section{Results}

VIRAL HEPATITIS IN THE GENERAL POPULATION

The incidence of viral hepatitis in Denmark during the past 50 years according to age is shown in the $\mathbb{Q}$ Figure. During the last 20 years adults have $\overrightarrow{\vec{\partial}}$

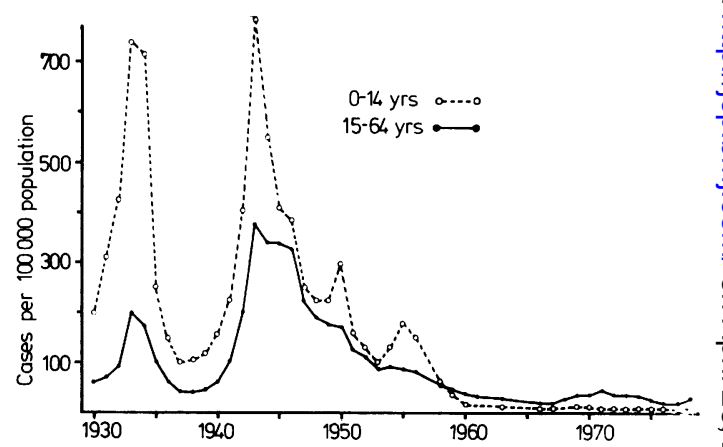

Viral hepatitis in Denmark 1930-78: incidence according to age. $\bigcirc$ 0-14 years; $15-64$ years.

constituted $3 / 4$ of all infected persons, and only $\underset{\mathbb{D}}{\overparen{D}}$ minor changes in the overall incidence have occurred, ? due primarily to infections in drug addicts. The $T$ epidemiological distribution of notified cases within the present study period, 1974-78, is shown in Table $1 \stackrel{\overbrace{}}{\Omega}$ and the geographical distribution in Table 2. The $\stackrel{\mathbb{Q}}{\varrho}$ rate in the metropolitan area was nearly twice the 
rate in the rest of the country, due mainly to the concentration of cases associated with drug abuse.

Distribution according to viral type is not generally available from the notifications. In the Copenhagen area, however, $40 \%$ of all hospital cases are known to be caused by hepatitis B virus. ${ }^{8}$

Table 1 Notified cases of viral hepatitis in Denmark 1974-78: distribution according to epidemiological categories

\begin{tabular}{lcr}
\hline Category & Total & $\%$ \\
& No. of cases & \\
\hline Drug addicts & 1134 & 29 \\
Foreign travel & 620 & 16 \\
Hepatitis contact & 444 & 11 \\
Blood transfusion & 88 & 2 \\
Others & 121 & 3 \\
Unknown origin & 1502 & 39 \\
Total & 3909 & 100 \\
\hline
\end{tabular}

Table 2 Notified cases of viral hepatitis in Denmark 1974-78: annual number of cases and incidence rate (per 100000 population) in different areas

\begin{tabular}{llll}
\hline $\begin{array}{l}\text { Hepatitis } \\
\text { category }\end{array}$ & $\begin{array}{l}\text { Greater } \\
\text { Copenhagen }\end{array}$ & $\begin{array}{l}\text { All other } \\
\text { areas }\end{array}$ & Total \\
\hline Drug addicts & $140(11 \cdot 1)$ & $87(2 \cdot 3)$ & $227(4 \cdot 5)$ \\
All others & $190(15 \cdot 0)$ & $365(9.6)$ & $555(11 \cdot 0)$ \\
Total & $330(26 \cdot 2)$ & $452(11.9)$ & $782(15 \cdot 5)$ \\
\hline
\end{tabular}

VIRAL HEPATITIS IN HEALTH CARE

\section{PERSONNEL}

In the period $1974-78,149$ out of 3909 reported cases $(4 \%)$ were working in health care institutions. No major changes in this rate were found within the period, the number of cases per year ranging from 25 to 35 . Table 3 shows the overall distribution according to profession and the type of institution.

An increased incidence was seen in hospital laboratory staff, in dentists in private practice, and in hospital physicians compared to the rate in the general population aged 15 to 64 years. Low rates were obtained for the remaining hospital groups, psychiatric hospital personnel and staff in institutions for the mentally retarded. No case of hepatitis was recorded among general practitioners.

An analysis of the possible sources of infection showed that $8 \%$ of the cases had had a possible exposure outside their professional work, such as travelling to endemic areas or exposure within the family. These patients were, however, equally distributed irrespective of their profession.

The percentage of hepatitis $B$ antigen positive cases is shown in Table 3. In hospital physicians, laboratory staffs, nursing staffs in psychiatric hospitals, and dentists, $70 \%$ of cases were type B infections, while among nurses and porters in
Table 3 Notified cases of viral hepatitis in Danish health care personnel 1974-78

\begin{tabular}{|c|c|c|c|c|}
\hline Category & $\begin{array}{l}\text { Total } \\
\text { No. of } \\
\text { cases }\end{array}$ & $\begin{array}{l}\text { Annual } \\
\text { incidence } \\
\text { rate/100000 }\end{array}$ & $\begin{array}{l}\text { Cases in } \\
\text { metro- } \\
\text { politan } \\
\text { area } \%\end{array}$ & $\begin{array}{l}\mathrm{HB} \mathrm{B}_{\mathrm{s}} \mathrm{Ag} \\
\text { positive } \\
\%\end{array}$ \\
\hline Hospital physicians & 24 & 89 & 42 & 61 \\
\hline Hospital nurses & 39 & 33 & 46 & 41 \\
\hline \multicolumn{5}{|l|}{ Hospital laboratory } \\
\hline & 22 & 110 & 64 & 82 \\
\hline Hospital assistant nurses & 24 & 25 & 58 & 52 \\
\hline Hospital porters & 9 & 51 & 67 & 43 \\
\hline Hospital cleaning staff & 6 & 22 & 67 & 67 \\
\hline \multicolumn{5}{|l|}{ Hospital clinical staff } \\
\hline total & 124 & 40 & 53 & 56 \\
\hline \multirow{2}{*}{$\begin{array}{l}\text { Dentists total } \\
\text { (Dentists in private } \\
\text { practice) }\end{array}$} & 17 & 77 & 59 & 77 \\
\hline & 15 & 97 & 54 & 73 \\
\hline \multicolumn{5}{|l|}{$\begin{array}{l}\text { Psychiatric hospital } \\
\text { nursing staff }\end{array}$} \\
\hline $\begin{array}{l}\text { Institutions for the } \\
\text { mentally retarded }\end{array}$ & & & & \\
\hline nursing staff & 6 & 13 & & 33 \\
\hline
\end{tabular}

general hospitals $45 \%$ were type B. Physicians and laboratory workers had a significantly higher rate $(71 \%)$ of hepatitis B infection than the nursing staff $(45 \%)(P<0.01)$.

In Table 4 the incidence of hepatitis in relation to the physician's specialty is shown. Similar high rates were found in surgeons and physicians, while no other specialty exhibited any apparent risk. Four physicians $(16 \%)$ reported that they had presumably been infected by haemodialysis patients. For hospital nurses the corresponding figure was $3(8 \%)$.

Table 4 Notified cases of viral hepatitis in Danish physicians 1974-78

\begin{tabular}{llll}
\hline Specialty & $\begin{array}{l}\text { Total No. of } \\
\text { cases }\end{array}$ & Annual incidence & $\begin{array}{c}\text { HBs Ag } \\
\text { positive \% }\end{array}$ \\
\hline $\begin{array}{l}\text { Surgery } \\
\text { General } \\
\text { medicine }\end{array}$ & 9 & 104 & 66 \\
$\begin{array}{l}\text { Pathology } \\
\text { All others }\end{array}$ & 7 & 108 & 57 \\
$\begin{array}{l}\text { General } \\
\text { practitioners }\end{array}$ & 0 & -54 & -57 \\
\hline
\end{tabular}

As in the general population, a higher risk of infection within the metropolitan area was demonstrated for some hospital personnel and for dentists. In Copenhagen dentists in private practice the incidence was 170 , compared to 75 for those in the rest of the country; for hospital workers the corresponding figures were 65 and 29 respectively. In the physician group no geographical diversity was observed. 


\section{Discussion}

The occupational risk of viral hepatitis in the health care profession has been extensively documented by serological studies of hepatitis B antibodies in various groups of personnel and has clearly related infection to blood exposure rather than to physical contact with patients. ${ }^{349}$

However, such data do not provide incidence rates and may reflect past contamination rather than present risk. Also these surveys show a majority of subclinical infections which, although indicative of risk areas, may be beneficial as they provide longlasting immunity. Thus serological surveys should be supplemented with data on clinical attack rates in order to achieve a rational basis for improved preventive measures.

Data similar to those given in the present report are sparse but do suggest that hepatitis $B$, and not hepatitis $A$, is the major concern of the health care professions. ${ }^{15} 71011$ Blood handling in surgery and in laboratory work is the main hazard, especially when dealing with infected haemodialysis patients. However, in the present series there were few cases among staff associated with haemodialysis, corresponding to the low rate of infected units in Denmark. ${ }^{12}$

In the present survey it could be shown that $70 \%$ of cases in the high-risk groups-laboratory staffs, hospital physicians, and dentists-were associated with hepatitis $\mathbf{B}$.

However, $55 \%$ of those cases in nursing staff with physical patient contact had non-B infections. Although the overall incidence was low for this group, it is possible that a risk of hepatitis A virus infection is present for some of these groups, and specific serological studies of anti-HAV among nurses and assistant nurses might be of interest.

A major determinant of the risk of infection for hospital workers as well as for dentists was the geographical association with the metropolitan area. However, in none of the subgroups was there a risk of more than 2 cases per 1000 per year, giving little justification for a more extensive prophylactic programme except for possible local high-risk settings not shown in the present survey.

A major problem in this type of evaluation is the reliability of the notification figures. The distribution in relation to the population data are probably realistic, but estimates of absolute risk figures may be less so. The number of notified cases of hepatitis in Denmark in 1977 and 1978 comprised only $75 \%$ of the number of hospital inpatients with this diagnosis (P Skinhøj, unpublished data). To assess this bias in the present study, all notified cases among laboratory staff were compared to a recent survey based on registrations made by the employers. ${ }^{13}$ Ten out of 15 cases known to have had viral hepatitis during the study period were also notified by the physicians and included in the present survey.

Assuming similar notification rates for the remaining personnel groups, it appears safe to conclude that an increased risk of hepatitis $B$ infection still exists for some metropolitan hospital employees and for dentists, whereas the problem does not at present warrant further preventive measures in general. Furthermore, recent long-term surveys ${ }^{1314}$ indicate that present awareness of the occupational risk of hepatitis has led to an acceptable diminution of hepatitis $B$ attack rates in laboratory staff.

\section{References}

${ }^{1}$ Maynard JE. Viral hepatitis as an occupational hazard in the health care profession. In: Vyas GN, Cohen SN, Schmid R, eds. Viral hepatitis. Philadelphia: Franklin Institute Press, 1978.

${ }^{2}$ Denes AE, Smith JL, Maynard JE, Doto IL, Berquist KR, Finkel AJ. Hepatitis B infection in physicians. Results of a nationwide seroepidemiologic survey. JAMA 1978;239:210-2.

3 Janzen J, Tripatzis I, Wagner U, Schlichter M, MüllerDethard E, Wolters E. Epidemiology of hepatitis B surface antigen (HBsAg) and antibody to HBsAg in hospital personnel. $J$ Infect Dis 1978;137:261-5.

${ }^{4}$ Pattison CP, Maynard JE, Berquist KR, Webster HM. Epidemiology of hepatitis B in hospital personnel. Am J Epidemiol 1975;101:59-64.

5 Mosley JW, Edwards VM, Casey G, Redeker AG, White E. Hepatitis B virus infection in dentists. $N$ Engl J Med 1975;293:729-34.

- Grist NR. Surveillance of hepatitis in laboratory staff: a seven year study. Med Microbiol Immunol 1978;166: 239-40.

${ }^{7}$ Nyström B, Ringertz O. Hepatit som yrkesrisk inom sjukvårdsyrkene-förekomst och profylax. Läkartidningen $1974 ; 71: 485-9$.

${ }^{8}$ Petersen P, Christoffersen P, Elling P, et al. Acute viral hepatitis: a survey of 500 patients. Scand J Gastroenterol 1974;9:607-13.

' Lewis ThL, Alter HJ, Chalmers TC, et al. A comparison of the frequency of hepatitis-B antigen and antibody in hospital and nonhospital personnel. $N$ Engl J Med 1973;289:647-51.

10 Williams SV, Huff JC, Feinglass EJ, Gregg MB, Hatch MH, Matsen JM. Epidemic viral hepatitis, type B, in hospital personnel. Am J Med 1974;57:904-11.

${ }^{11}$ Aldershvile J, Brock A, Dietrichson O, et al. Hepatitis B virus infections among Danish dentists. $J$ Infect Dis 1978;137:63-6.

12 Skinhøj P, Steiness I. Hepatitis and hepatitis-associeret antigen (HAA) i danske dialysecentre. Ugeskrift for Laeger 1971 ;133:240-3.

${ }^{13}$ Skinhøj P. Viral hepatitis in Danish clinical chemical laboratories 1968-1978: incidence rates aetiology and risk factors. Scand J Clin Lab Invest 1980;40:23-6. 
14 Grist NR. Hepatitis in clinical laboratories 1977-78. J Clin Pathol 1980;33:471-3.
Requests for reprints to: Dr P Skinhøj, Department of Infectious Diseases, Rigshospitalet, DK-2200 Copenhagen N, Denmark.

\section{The March 1981 Issue}

\section{THE MARCH 1981 ISSUE CONTAINS THE FOLLOWING PAPERS}

\section{Humphrey Kay GERARD SLAVIN}

In pursuit of safety REO WILLIAMS

Conception and development of the Fetal Tissue Bank SYLVIA D LAWLER

Acute lymphoblastic leukaemia: four-year survivals old and new RM HARDISTY, MORWENNA M TILL, AND J PETO

Enzyme and membrane markers in leukaemia: recent developments AV HOFFBRAND AND G JANOSSY

Serial study of C-reactive protein during infection in leukaemia PE ROSE, SA JOHNSON, M MEAKIN, PH MACKIE, AND J STUART

An unexpected fungal infection in a patient with leukaemia BERYL JAMESON, RL CARTER, JG WATSON, AND RJ HAY

Bloodstream infections and perinatal mortality ROSALINDE HURLEY AND J DE LOUVOIS

What is clinical immunology? AM DENMAN
Spectroscopy, colorimetry, and biological chemistry in the nineteenth century MG RINSLER

Human platelet monoamine oxidase activity in health and disease: a review M SANDLER, MA REVELEY, AND VIVETTE GLOVER

Immunoperoxidase localisation of human placental lactogen: a marker for the placental origin of the giant cells in 'syncytial endometritis' of pregnancy EADIE HEYDERMAN, AR GIBBONS, AND SW ROSEN

Surface topography of the female bladder trigone R DAVIES AND AC HUNT

Monoclonal antibodies to detect human tumours: an experimental approach $v$ MOSHAKIS, RAJ MCILHINNEY, D RAGHAVAN, AND AM NEVILLE

Immunocytochemical studies of blood group A, $H, I$, and $i$ antigens in gastric mucosae of infants with normal gastric histology and of patients with gastric carcinoma and chronic benign peptic ulceration ANUPSHEELA KAPADIA, TEN FEIZI, D JEWELL, JEAN KEELING, AND G SLAVIN

\section{Book reviews}

Copies are still available and may be obtained from the PUBLISHING MANAGER, BRITISH MEDICAL ASSOCIATION, TAVISTOCK SQUARE, LONDON WC1H 9JR, price $£ 3.00$, including postage 